\title{
A Stochastic Modelling Approach to Forecast Real-time Ice Jam Flood Severity Along the Transborder (New Brunswick/Maine) Saint John River of North America
}

Apurba Das ( $\square$ apurba.das@usask.ca )

University of Saskatchewan School of Environment and Sustainability https://orcid.org/0000-0002-4431-8593

Sujata Budhathoki

University of Saskatchewan

Karl-Erich Lindenschmidt

University of Saskatchewan

\section{Research Article}

Keywords: ice jam, flood forecasting, stochastic approach, flood outlook

Posted Date: September 2nd, 2021

DOI: https://doi.org/10.21203/rs.3.rs-748153/v1

License: (c) (i) This work is licensed under a Creative Commons Attribution 4.0 International License. Read Full License 


\section{Abstract}

Ice jam floods (IJF) are a major concern for many riverine communities, government and non-government authorities and companies in the higher latitudes of the northern hemisphere. Ice jam related flooding can result in millions of dollars of property damages, loss of human life and adverse impacts on ecology. Ice jam flood forecasting is challenging as its formation mechanism is chaotic and depends on numerous unpredictable hydraulic and river ice factors. In this study, Modélisation environnementale communautaire - surface hydrology (MESH), a semi-distributed physically-based land-surface hydrological modelling system was used to acquire a 10day flow forecast, an important boundary condition for any modelling of river ice-jam flood forecasting. A stochastic modelling approach was then applied to simulate hundreds of possible ice-jam scenarios using the hydrodynamic river ice model RIVICE within a Monte-Carlo Analysis (MOCA) framework for the Saint John River from Fort Kent to Grand Falls. First, a 10-day outlook was simulated to provide insight on the severity of ice jam flooding during spring breakup. Then, 3-day forecasts were modelled to provide longitudinal profiles of exceedance probabilities of ice jam flood staging along the river during the ice-cover breakup. Overall, results show that the stochastic approach performed well to estimate maximum probable ice-jam backwater level elevations for the spring 2021 breakup season.

\section{Introduction}

Ice jam related floods are a key concern for many riverside communities during freeze-up and spring breakup in Canada. Ice jam floods can be more devastating than open-water floods, as their occurrence can be extremely rapid and suddenly, allowing very little time to implement an emergency measure. Ice related floods can cause millions of dollars of property and businesses losses, damaging homes and infrastructure, death of human life and various detrimental impacts on the aquatic environment (e.g. fish mortality).

The Saint John River is one of the ice-jam prone rivers in Canada. The majority of flood damages in the province occur due to ice-jam flooding within the Saint John River basin (Humes and Dublin, 1988). Some studies indicate that the severity of the flooding would continue to rise due to climate change (Beltaos, 2002, 2004). Flow forecasting is carried out by the Hydrology Centre at the Environment Department of the New Brunswick Government using a hydrological model. However, the model is based on an open-water case and cannot consider the ice effects on the river staging. Therefore, this forecasting cannot reflect the actual severity of flooding, as ice jams can significantly increase river stages above those during open-water floods. To reduce this limitation, Beltaos et al. (2012) attempted to forecast ice-jam water levels along the Saint John River from Dickey to Grand Falls using the HEC-RAS model in steady-state mode in an operational context. The results show that the calibrated model could simulate probable ice jam scenarios and associated flooding severity. However, this type of forecasting greatly depends on real-time data availability and a clear understanding of the dynamic behaviour of ice cover during spring breakup. Moreover, there is still no publicly available model that could predict the timing and locations of ice jam formation.

In recent years, a stochastic modelling approach has been applied to several Canadian rivers (e.g. Athabasca, Peace and Red rivers) to predict ice jam water elevations (Lindenschmidt et al., 2019; Rokaya et al., 2019; Williams et al., 2021). In this approach, many probable scenarios of ice jams are simulated using a set of randomly selected variables to predict the potential severity of flooding (Lindenschmidt, 2020; Das, 2021). One of the advantages of this approach is it can provide a range of maximum and minimum values to select modelling parameters instead of a specific or single parameter value. Therefore, different distributions of modelling parameters and boundary 
conditions can be used to simulate hundreds of probable ice jam scenarios. For example, as the location of ice jams are difficult to predict during spring breakup, a range of ice jam locations can be used as model input.

Lindenschmidt et al. (2019) applied this approach in an operational flood forecasting context to predict maximum probable ice jam water level elevations along the Athabasca River at Fort McMurray, Canada.

The main purpose of this study is to develop a stochastic modelling framework for an operational real-time ice-jam flood forecasting system along the Saint John River, Canada. The specific objectives are i) to provide an ice-jam flood outlook for spring ice-cover breakup and ii) to forecast probable maximum ice-jam backwater level elevations.

\section{Methodology \\ 2.1 Study Area}

The hydrological model setup to simulate flows along the Saint John River extends across the Saint John River Basin. This basin is situated in northeastern North America (Fig. 1), covering more than $55,000 \mathrm{~km}^{2}$ across the United States and Canada. While a major portion of the basin is located in Canada (51\% and $13 \%$ in the provinces of New Brunswick and Quebec, respectively), the remaining portion (36\%) is situated in the State of Maine, USA (Kidd et al., 2011). The Saint John River is more than $700 \mathrm{~km}$ long, flows from northern Maine, USA to western New Brunswick, Canada, before draining into the Bay of Fundy at Saint John, Canada. The total elevation drop of the river is about $480 \mathrm{~m}$ (Beltaos et al., 2012).

The Saint John River basin has mixed humid continental and maritime climates (Kidd, Curry and Munkittrick, 2011). The average annual precipitation is measured to be $1100 \mathrm{~mm}$, in which $30 \%$ is snowfall (Beltaos et al., 2012). The mean annual discharge is approximately $1100 \mathrm{~m}^{3} / \mathrm{s}$ with a peak flow condition in later spring. The soil type in the basin is dominated by "forest soil" - humo-ferric podzols and gray luvisols. The land cover mostly consists of forests $(70 \%)$, with some patches of cropland $(6 \%)$ and wetlands $(6 \%)$. There are three large hydroelectric reservoirs in the basin, impounded by the Grand Falls, Beechwood and Mactaquac dams. Since there is currently no active hydrometric station in the main river channel downstream of Fredericton hence the outlet station for the hydrological model of the basin was taken to be at the Mactaquac Dam, which reduces the hydrological model domain area to $41,000 \mathrm{~km}^{2}$.

The hydraulic model domain extends from Fort Kent to Grand Falls, an approximate $94 \mathrm{~km}$ long river reach. This portion of the river is prone to ice jam formation during spring breakup due to its geomorphological settings. The reach from Fort Kent to Edmundston is relatively steep with a series of rapids. The strech from Edmundston to Grand Falls has a relatively milder slope, shallow riverbed, and many islands and sandbars that splits the main river channels into multiple sub-channels.

Some hydraulic gauge stations record daily river flows and water levels along the study site. The United States Geological Survey (USGS) operates the gauging stations at Dickey and Fort Kent, ECCC's Water Survey of Canada operate the gauge at Edmundston and New Brunswick Power own the gauge at Grand Falls. The hydrological model is calibrated and validated using streamflow records from Dickey and Grand Falls. Since the hydraulic model was calibrated and validated using the water levels recorded at the Edmundston gauge station and the model simulates ice jam backwater level profiles, the model framework was developed to forecast the severity of ice jams downstream of Edmundston. 


\subsection{MESH hydrological model}

MESH is a physically-based hydrological land-surface model from Environment and Climate Change Canada (ECCC) (Pietroniro et al., 2007) and has been widely used in different parts of Canada, from small to large catchments (Mengistu \& Spence, 2016; Haghnegahdar et al., 2017; Yassin et al., 2017; Lindenschmidt et al., 2019;

Budhathoki et al., 2020; Rokaya et al., 2020). MESH uses a grouped response unit (GRU) approach to capture basin heterogeneity. It has a grid-based modelling system which is composed of three major components (i) a vertical exchange of water within a grid cell between the land surface and the atmosphere (ii) the routing of lateral fluxes and (iii) the generation of surface and sub-surface runoff. MESH uses the Canadian Land Surface Scheme (CLASS) (Verseghy, 1991) for the vertical generation and exchange of lateral fluxes. WATROF (Soulis et al., 2000) and PDMROF (Mekonnen et al., 2014) are the two scheme used to account for lateral fluxes. The routing of surface and subsurface runoff is performed using WATROUTE (Kouwen, 2016).

\subsection{Meteorological Input for MESH}

MESH requires seven meteorological forcing inputs: precipitation, wind speed, air temperature, specific humidity, incoming longwave radiation, barometric pressure and incoming shortwave radiation. For model calibration and validation, all inputs except precipitation were taken from combined gridded datasets of Global Environmental Multiscale (GEM) model (Côté et al., 1998; Yeh et al., 2002) which is available at an hourly temporal resolution and at the spatial resolution of $15 \mathrm{~km}$. The precipitation inputs were taken from the Canadian Precipitation Analysis (CaPA) (Mahfouf et al., 2007) datasets which are available at 6 hour time intervals at a spatial resolution of $10 \mathrm{~km}$. CaPA is found to be a reliable precipitation product for the Canadian domain (Boluwade et al., 2018).

For streamflow forecasting, all the meteorological forcing data were retrieved from Global Deterministic Prediction System (GDPS). GDPS is an operational forecasting system, based on the GEM model from ECCC which provides deterministic predictions of atmospheric variables with a 10-day lead time (Bélair et al., 2009; Charron et al., 2012). The forecasts are produced two times a day (00 UTC and 12 UTC) at 3-hourly temporal resolution and has an approximate $25 \mathrm{~km}$ spatial resolution.

\subsection{MESH set up and calibration}

"The topographic data for SJRB were obtained from the hydrologically adjusted elevation of MERIT Hydro which is at a resolution of 3 arc-second resolution ( $90 \mathrm{~m}$ at the equator) (http://hydro.iis.utokyo.ac.jp/ yamadai/MERIT_Hydro/) (Yamazaki et al., 2019). The landcover data were derived from the Commission for Environmental Cooperation (CEC) land cover database in $30 \mathrm{~m}$ resolution (http://www.cec.org/north-american-environmental-atlas/land-cover-2010-landsat-30m/). The vegetation parameters were obtained from literature (Kidd et al., 2011) and the CLASS manual (Verseghy, 2009) and the soil texture information was obtained from the Unified North American Soil Map (UNASM) (LIU et al., 2014) for different soil depths." (Budhathoki et al., submitted). Six vertical soil profile layers of $10 \mathrm{~cm}, 35 \mathrm{~cm}, 120 \mathrm{~cm}, 260$ $\mathrm{cm}, 310 \mathrm{~cm}$ and $410 \mathrm{~cm}$ were defined from the surface boundary in MESH. The model was built with a grid resolution of 0.125 deg. (approx. $10 \mathrm{~km}$ ), resulting in 373 grid cells. Nine GRUs were created based on the landcover variability in the basin. The preprocessing of the spatial data was conducted using ECCC's Green Kenue software (EnSim Hydrologic, 2014) to generate drainage networks and other topographically driven basin characteristics such as slope and channel length. The discharge data were retrieved from ECCC's database HYDAT and the reservoir inflows and outflows were retrieved from the New Brunswick Power company. 
The calibration was performed using parallel DDS algorithm in OSTRICH (Matott, 2005) with the Nash Sutcliffe Efficiency (NSE) as the objective function. The sensitive parameters were selected based on Haghnegahdar et al. (2017) and ten parameters of six dominant GRU's were calibrated. The model was calibrated for the period 20022010 considering the first year (Oct 2002 - Oct 2003) as the model spin-up period. The validation was then performed using the subsequent six years (2011-2018).

\subsection{Streamflow Forecast}

Forecasting the basin's streamflow involves a two-step process, first running the MESH model in hindcast mode, which saves the state variables until the previous day (yesterday) of the forecast period and then performing the flow forecast for the next 10 days (from today) with the saved state variables. It is important to save and update the basin state variables and hydrologic conditions everyday so that the initial hydrologic conditions for running the model are always accurate. Figure 2 shows the schematic view of the MESH operational forecasting setup for the SJRB.

In the hindcasting mode, the forcing data for precipitation were obtained from CaPA and other meteorological forcing data were retrieved from the GEM system. In the forecasting mode, all the meteorological forcing data were retrieved from the GDPS system. MESH was run at an hourly time step in the hindcasting mode and 3-hourly in the forecasting mode to match the temporal resolution of the meteorological data.

\subsection{RIVICE hydraulic model}

RIVICE is a one-dimensional hydrodynamic model that simulates various river ice phenomena, including the formations of frazil ice, border ice, solid ice covers and ice jams. RIVICE solves the Saint Venant equations for transient flows and water levels using an implicit finite difference scheme. A user usually calibrates the time steps and appropriate lengths of the simulation based on specific sites and purposes. Surveyed cross-sections are the primary inputs to set up the model structure along a river. Moreover, the model requires various hydraulic and river ice parameters and boundary condition inputs to simulate these processes. A conceptual diagram of ice jam simulations and their require variables is shown in Fig. 3. Some of these parameters and boundary conditions are user-defined or calibrated based on historical events along the model domain. Table I briefly describes all of the parameters and boundary conditions. For further details about the RIVICE the reader may refer to the online manual (http://giws.usask.ca/rivice/Manual/RIVICE_Manual_2013-01-11.pdf) and to Lindenschmidt (2017).

Table I Description of RIVICE parameters and boundary conditions 


\begin{tabular}{|lll|}
\hline Inputs & Description & Units \\
\hline Boundary Conditions & & \\
\hline$W$ & Upstream river discharge & $\mathrm{m}^{3} / \mathrm{s}$ \\
\hline$V_{i c e}$ & Downstream water level & $\mathrm{m}$ a.s.I \\
$\mathrm{X}$ & Inflowing volume of ice & $\mathrm{m}^{3}$ \\
\hline Parameters & Toe of the ice-jam location & none \\
\hline $\mathrm{PC}$ & & \\
\hline $\mathrm{FT}$ & Porosity of ice-cover & $\mathrm{none}$ \\
\hline $\mathrm{PS}$ & Thickness of ice-cover & $\mathrm{m}$ \\
\hline $\mathrm{ST}$ & Porosity of slush pans & $\mathrm{none}$ \\
\hline$v_{d e p}$ & Thickness of slush pans & $\mathrm{m}$ \\
\hline$v_{e r}$ & ice deposition velocity & $\mathrm{m} / \mathrm{s}$ \\
\hline$n_{b e d}$ & ice erosion velocity & $\mathrm{m} / \mathrm{s}$ \\
\hline$n_{8 m}$ & Longitudinal to vertical force ratio & $\mathrm{none}$ \\
\hline$K 1$ & ice roughness & $\mathrm{s} / \mathrm{m}^{\square}$ \\
\hline
\end{tabular}

\subsection{Stochastic framework for forecasting}

In the stochastic framework (Fig. 4), the RIVICE hydrodynamic model is placed within a Monte-Carlo Analysis (MOCA) framework to simulate hundreds of ice jam scenarios using randomly selected sets of parameters and boundary conditions. To select random values of the parameters and boundary conditions, minimum and maximum values of the inputs were extracted from gauge records and the calibration data of previous studies along the model domain. While the uniform distribution of most of the parameters and toe of ice jam location are used to select the random values for the MOCA, an extreme value distribution (Gumbel) was implemented for two important boundary conditions - river discharge and the inflowing volume of ice.

An extreme value distribution was developed for river discharge using observed flows recorded at the Fort Kent gauging station during spring breakup. The location and scale parameters of the distribution were then used to select the random values from the maximum and minimum range of forecasted flows. The 3-day probable streamflow data from the MESH hydrological model was used to select the maximum and minimum range of the flows. The lateral flow inputs from various major tributaries along the model domain were also estimated by establishing linear relationships between the Fort Kent discharge and tributary flows. 
The observed flow frequency distribution during spring breakup was used as an input in the MOCA framework. The volume-of-ice frequency distribution was then calibrated by comparing (i) the frequency distribution of the ensemble of stages simulated at Edmundston and (ii) the frequency distribution of the water level elevations recorded at the Edmundston gauge during ice-jam events. If the two distributions did not coincide, the volume-ofice frequency distribution was adjusted and the MOCA repeated to yield a new "simulated" frequency distribution of stages at Edmundston for comparison, again, with the "observed" frequency distribution of the water level elevations recorded at Edmundston. The process is repeated until the "simulated" and "observed" frequency distributions of the volume of ice consistently coincided. A more detailed description of this process can be obtained from Lindenschmidt (2020; p. 181-183).

Once all the parameters and boundary conditions distributions were established, the framework was used to produce a seasonal outlook (before the breakup initiation along the model domain) of the severity of ice jam from 22 March 2021. The 3-day forecasting simulation began on 24 March 2021. Additional information was updated using the New Brunswick government's daily interactive map of ice observation, especially important to track the toe of ice jam location.

\section{Result And Discussion}

\subsection{MESH calibration and validation}

The results of the MESH calibration and validation for the gauging station 01AF002 (Saint John River at Grand Falls) is shown in Fig. 5. The observed and simulated flows are in good agreement with each other. The NSE value of 0.89 and $\log$ (NSE) value of 0.84 were achieved for the calibration period whereas for the validation period, values of NSE $=0.88$ and $\log ($ NSE $)=0.85$ were obtained.

\subsection{MESH 10-day flow forecasts}

10-day flow forecasts were simulated using MESH. Figure 6 shows the flow forecast at the Fort Kent station during the spring of 2021. MESH was able to forecast the timing of the rise in the flows with a Pbias of $+15 \%$ (based on the average of a seven-day daily forecast). The forecasted flow data from these events are used as an important boundary condition to assist parallel ice-jam forecasting.

\subsection{RIVICE calibration and validation}

The RIVICE model is calibrated and validated using historical ice jam events in 1991 and 2008 along the Saint John River. Observed water level and related data of these events were obtained from the study by Beltaos et al. (2012). First hydraulic and river ice parameters were calibrated until good agreement was obtained between simulated and observed water level profiles. Figure 7 (left panel) shows the RIVICE calibration result for the ice jam event of 1991 that occurred upstream of St. Leonard. To validate the model, the same calibration data were used to simulate the ice jam that occurred in 2009. Figure 7 (right panel) shows a good agreement between observed and simulated water levels of the 2009 ice jam event.

\subsection{Ice cover breakup in spring 2021}


Spring ice cover breakup in 2021 was triggered by consistent warm air temperatures (above $0^{\circ} \mathrm{C}$ ) from 20 to 25 March 2021. During this period, river discharge increased significantly from 124 to $1241 \mathrm{~m}^{3} / \mathrm{s}$ due to rapid snowmelt (Fig. 8). By 24 March 2021, ice covers began to crack and melt out forming open-water leads in the ice cover. On 25 March 2021, a long open-water section with intermittent fragmented ice was observed from downstream of Frenchville to Grand Isle. The ice cover from Fort Kent to Edmundston completely broke up with ice moving downstream of Edmundston by 26 March 2021. On 27 March 2021, an ice jam formed immediately upstream of Sainte-Anne-de-Madawaska, which extended upstream for more than $20 \mathrm{~km}$ by 28 March 2021. On this day, the water level elevation at Edmundston gauge station increased to the season maximum of $138.126 \mathrm{~m}$ a.s.l.

\subsection{Ice jam flood outlook for spring 2021}

The main goal of the ice jam flood outlook is to provide a preliminary forecast for the breakup period. Since MESH usually simulates 10-day flow forecasts, the outlook results present the potential maximum ice-jam water level profiles for the next 10 days. Figure 9 shows the ice-jam flood outlook from 22 to 31 March 2021. The outlook predicted the maximum water level elevation due to ice jam formation to be lower than the flood level ( $140.5 \mathrm{~m}$ a.s.I according to the New Brunswick Government river watch website). The comparison between observed water level and simulated water level profiles shows that the simulated outlook (90th percentile) was fairly accurate to predict maximum water level elevations.

\subsection{Ice jam flood forecasting during spring 2021}

The 3-day ice jam flood forecasts began on 24 March 2021. Each day a total of 250 ice jam scenarios were simulated in the stochastic modelling framework to predict the severity of ice jam flooding along the study site. Figure 10 shows the forecasting results from 24 to 27 March 2021, indicating the 10th, 50th, and 90th percentiles of the ice jam water level profiles. As the ice cover was still intact on 24 March, the simulations slightly overestimated the water level elevations along the river. The forecasting results started to improve when the ice cover broke up from 25 to 27 March 2021. The ice jam flood forecast from 27 March 2021 compares well with the observed water level elevations at the Edmundston gauge. The results show that the mean and maximum observed water level elevations at Edmundston were within the 50th and 90th percentiles of the forecasted water level profiles. Overall, the 3-day flood forecasting was effective to estimate the backwater level conditions during breakup.

\section{Potential Sources Of Error}

Although the stochastic approach for ice jam flood forecasting provides a reasonable outcome to predict the severity of flooding, there are still some limitations and uncertainties associated with the assumptions and parameter selection.

- the volume of inflowing ice has been calibrated and selected as an independent parameter, which may not always be the case, as this variable depends on streamflow conditions. For example, low spring flow conditions may result in thermal breakup and significant ice melt, leading to relatively small ice volumes to form ice jams. The opposite is true for the high spring flows, however in this stochastic approach the model simulation can be incorporated with high flows with low volumes to mimic under-developed ice jams. Moreover, these uncertainties can also be associated with the errors in the selected parameter distributions. 
- the toe of the ice-jam location is not always uniformly distributed along the river and there are some preferred icelodgment sites. Although the study was used observed ice breakup and potential ice jam toe locations, there are still some discrepancies between forecasting setup and observed information. Hence the incorrect selection of toe location range can create an additional error in the forecasting results.

- tribuatary inflows in the model domain were considered as a mean flow, which may not reflect the actual river flow condition. Since the hydrological model forecasting setup only provides the upstream flow conditions of the main model domain, providing tributary flows dynamically would not decrease the overall error.

- the study considered the peak breakup water level due to ice-jam formation along the river stretch downstream of Edmundston; therefore the results were only validated using the observed water level recorded at the Edmundston gauge station. Therefore, there are maybe some biases that should be considered to assess the forecasting results.

\section{Conclusion}

A stochastic modelling framework was developed to forecast the severity of ice jam flooding along the Saint John River from Fort Kent to Grand Falls. The framework loosely coupled a hydrological land-surface model MESH with a hydrodynamic river ice model RIVICE to simulate hundreds of probable ice jam scenarios using a Monte-Carlo analysis.

Within this stochastic framework, an outlook was provided at the beginning of the breakup to assess the 10-day ice jam severity along the study site. This is one of the novelties in the field of ice jam flood forecasting. This outlook may help to provide early warning and extra preparation time to improve mitigation strategies. The 3-day

ice jam flood forecasting was also able to simulate maximum water levels more accurately. Overall, the framework can be used in real-time mode for operations ice-jam flood forecasting and mitigation management and planning.

\section{Declarations}

\section{Ethical Approval}

Not Applicable

\section{Consent to Participate}

Not Applicable

\section{Consent to Publish}

Not Applicable

\section{Authors Contributions}

$A D$ carried out all the data analyses and wrote most of the sections of the manuscript. SB provided hydrological model results and wrote some sections of the manuscript. KEL conceptually helped to develop the paper and reviewed the manuscript throughout the process.

\section{Funding}


Global Water Future, Global Institute for Water Security, University of Saskatchewan

\section{Competing Interests}

None

\section{Data Availability Statement}

The historical hydrometric and meteorological data are available from Environment and Climate Change Canada and Unites State Geological Survey (USGS). The model simulated data and code are available from the corresponding author upon reasonable request.

\section{Conflict of Interest}

None

\section{Acknowledgement}

The authors thank the University of Saskatchewan's Global Water Future program at the Global Institute for Water Security for their funding support of this research. Thanks also go to New Brunswick Power for the water levels and flows recorded at Grand Falls.

\section{References}

1. Beltaos, S. (2002). Effects of climate on mid-winter ice jams. Hydrological Processes, 16(4), 789-804.

2. Beltaos, S. (2004). Climate impacts on the ice regime of an Atlantic river. Hydrology Research, 35(2), 81-99.

3. Bélair, S., Roch, M., Leduc, A.-M., Vaillancourt, P. A., Laroche, S., \& Mailhot, J. (2009). Medium-range quantitative precipitation forecasts from Canada's new 33-km deterministic global operational system. Weather and forecasting, 24(3), 690-708.

4. Beltaos, S., Tang, P., \& Rowsell, R. (2012). Ice jam modelling and field data collection for flood forecasting in the Saint John River, Canada. Hydrological Processes, 26(17), 2535-2545.

5. Boluwade, A., Zhao, K.-Y., Stadnyk, T. A., \& Rasmussen, P. (2018). Towards validation of the Canadian precipitation analysis (CaPA) for hydrologic modeling applications in the Canadian Prairies. Journal of Hydrology, 556, 1244-1255.

6. Budhathoki, S., Rokaya, P., \& Lindenschmidt, K.-E. (2020). Improved modelling of a Prairie catchment using a progressive two-stage calibration strategy with in situ soil moisture and streamflow data. Hydrology Research, 51(3), 505-520.

7. Charron, M., Polavarapu, S., Buehner, M., Vaillancourt, P., Charette, C., Roch, M., . . MacPherson, S. (2012). The stratospheric extension of the Canadian global deterministic medium-range weather forecasting system and its impact on tropospheric forecasts. Monthly Weather Review, 140(6), 1924-1944.

8. Côté, J., Gravel, S., Méthot, A., Patoine, A., Roch, M., \& Staniforth, A. (1998). The operational CMC-MRB global environmental multiscale (GEM) model. Part I: Design considerations and formulation. Monthly Weather Review, 126(6), 1373-1395.

9. Das, A. (2021). Stochastic modelling approach to improve ice-jam flood risk management (Doctoral dissertation, University of Saskatchewan). 
10. Doyle, P. F. (2009). Beltaos, Spyros (Editor). 2008. River Ice Breakup. Canadian Water Resources Journal, 34(1), 95-97.

11. Haghnegahdar, A., Razavi, S., Yassin, F., \& Wheater, H. (2017). Multicriteria sensitivity analysis as a diagnostic tool for understanding model behaviour and characterizing model uncertainty. Hydrological Processes, 31(25), 4462-4476.

12. Humes, T. M., \& Dublin, J. (1988). A comparison of the 1976 and the 1987 St. John River ice jam flooding with emphasis on antecedent conditions. In Proceedings of the Workshop on Hydraulics of River Ice/Ice Jams (pp. 43-62).

13. Kidd, S D, R A Curry, and K R Munkittrick. The Saint John River: A State of the Environment Report. Fredericton, New Brunswick, Canada: Canadian River Institute - University of New Brunswick,2011. https://www.unb.ca/research/institutes/cri/_resources/pdfs/criday2011/cri_sjr_soe_final.pdf

14. Kouwen, N. (2016). WATFLOOD/WATROUTE Hydrological Model Routing and Flood Forecasting System, User's Manual: University of Waterloo, Waterloo, ON.

15. Lindenschmidt, K.-E., Rokaya, P., Das, A., Li, Z., \& Richard, D. (2019). A novel stochastic modelling approach for operational real-time ice-jam flood forecasting. Journal of Hydrology, 575, 381-394.

16. Lindenschmidt, K.-E. (2020) River ice processes and ice flood forecasting - a guide for practitioners and students. Springer Nature Switzerland AG. 267 pp. https://doi.org/10.1007/978-3-030-28679-8

17. Lindenschmidt, K.-E. (2017). RIVICE-a non-proprietary, open-source, one-dimensional river-ice model. Water, 9(5), 314.

18. LIU, S., Wei, Y., Post, W., Cook, R., Schaefer, K., \& Thornton, M. (2014). NACP MsTMIP: Unified North American Soil Map. ORNL DAAC.

19. Mahfouf, J. F., Brasnett, B., \& Gagnon, S. (2007). A Canadian precipitation analysis (CaPA) project: Description and preliminary results. Atmosphere-ocean, 45(1), 1-17.

20. Matott, L. S. (2005). OSTRICH: An optimization software tool: Documentation and users guide. University at Buffalo, Buffalo, NY.

21. Mekonnen, M., Wheater, H., Ireson, A., Spence, C., Davison, B., \& Pietroniro, A. (2014). Towards an improved land surface scheme for prairie landscapes. Journal of Hydrology, 511, 105-116.

22. Mengistu, S., \& Spence, C. (2016). Testing the ability of a semidistributed hydrological model to simulate contributing area. Water Resources Research, 52(6), 4399-4415.

23. Pietroniro, A., Fortin, V., Kouwen, N., Neal, C., Turcotte, R., Davison, B., . . Evora, N. (2007). Development of the MESH modelling system for hydrological ensemble forecasting of the Laurentian Great Lakes at the regional scale. Hydrology and Earth System Sciences, 11(4), 1279-1294.

24. Rokaya, P., Wheater, H., \& Lindenschmidt, K.-E. (2019). Promoting sustainable ice-jam flood management along the Peace River and Peace-Athabasca Delta. Journal of Water Resources Planning and Management, 145(1), 04018085.

25. Rokaya, P., Peters, D. L., Elshamy, M., Budhathoki, S., \& Lindenschmidt, K. E. (2020). Impacts of future climate on the hydrology of a northern headwaters basin and its implications for a downstream deltaic ecosystem. Hydrological Processes, 34(7), 1630-1646.

26. Soulis, E. D., Snelgrove, K. R., Kouwen, N., Seglenieks, F., \& Verseghy, D. L. (2000). Towards closing the vertical water balance in Canadian atmospheric models: coupling of the land surface scheme CLASS with the distributed hydrological model WATFLOOD. Atmosphere-ocean, 38(1), 251-269.

Page $11 / 19$ 
27. Tang, P., \& Beltaos, S. P. Y. R. O. S. (2008, May). Modeling of river ice jams for flood forecasting in New Brunswick. In Proceedings, 65th Eastern Snow Conference (pp. 167-178). Fairlee (Lake Morey) Vermont, USA, Bridgewater State College and ERDC-CRREL.

28. Williams, B. S., Das, A., Johnston, P., Luo, B., \& Lindenschmidt, K.-E. (2021). Measuring the skill of an operational ice jam flood forecasting system. International Journal of Disaster Risk Reduction, 52, 102001.

29. Yamazaki, D., Ikeshima, D., Sosa, J., Bates, P. D., Allen, G. H., \& Pavelsky, T. M. (2019). MERIT Hydro: a highresolution global hydrography map based on latest topography dataset. Water Resources Research, 55(6), 5053-5073.

30. Yassin, F., Razavi, S., Wheater, H., Sapriza-Azuri, G., Davison, B., \& Pietroniro, A. (2017). Enhanced identification of a hydrologic model using streamflow and satellite water storage data: A multicriteria sensitivity analysis and optimization approach. Hydrological Processes, 31(19), 3320-3333.

31. Yeh, K.-S., Côté, J., Gravel, S., Méthot, A., Patoine, A., Roch, M., \& Staniforth, A. (2002). The CMC-MRB global environmental multiscale (GEM) model. Part III: Nonhydrostatic formulation. Monthly Weather Review, 130(2), 339-356.

\section{Figures}




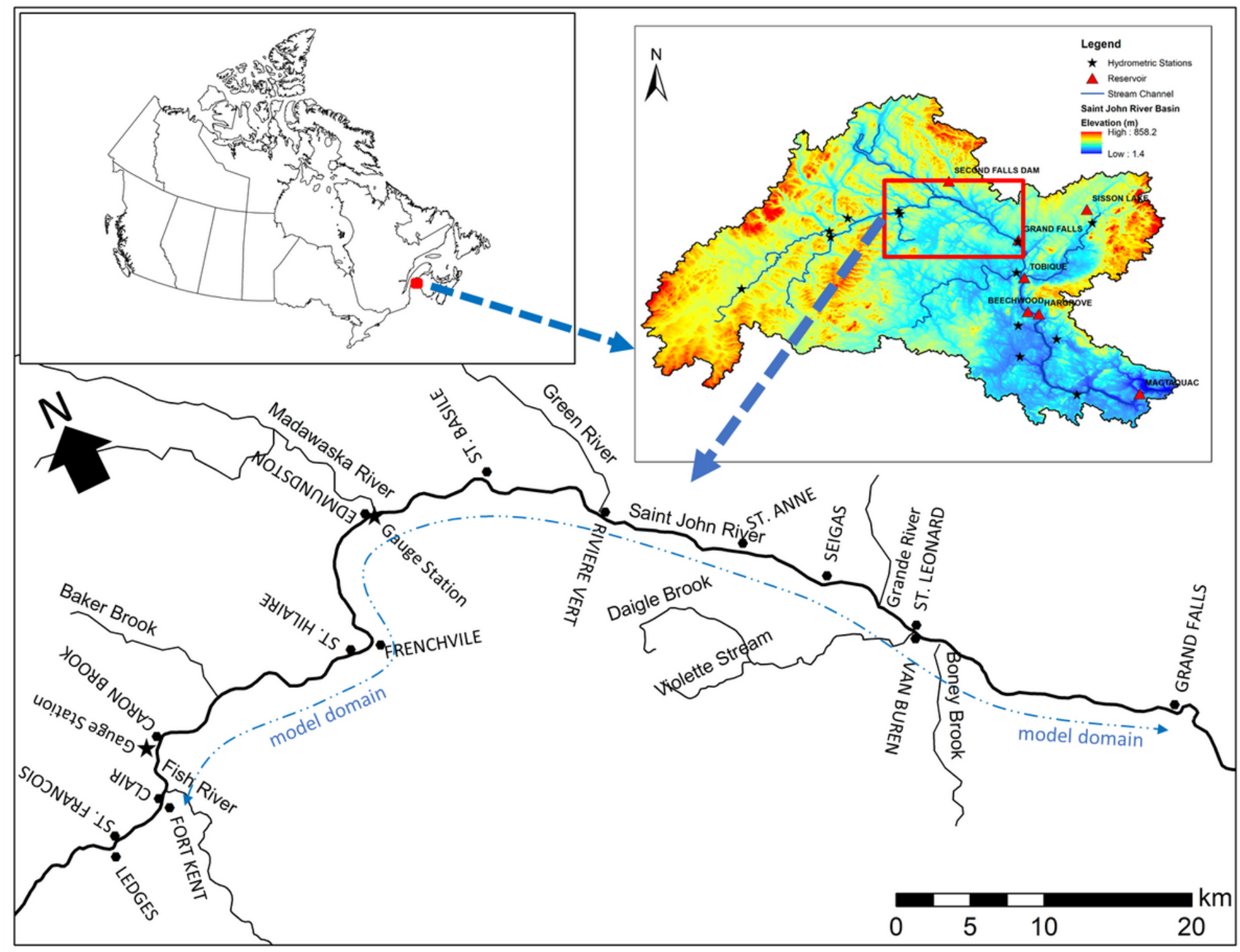

Figure 1

Study site including hydrological and hydraulic model domains of Saint John River and its basin. 
Day 1

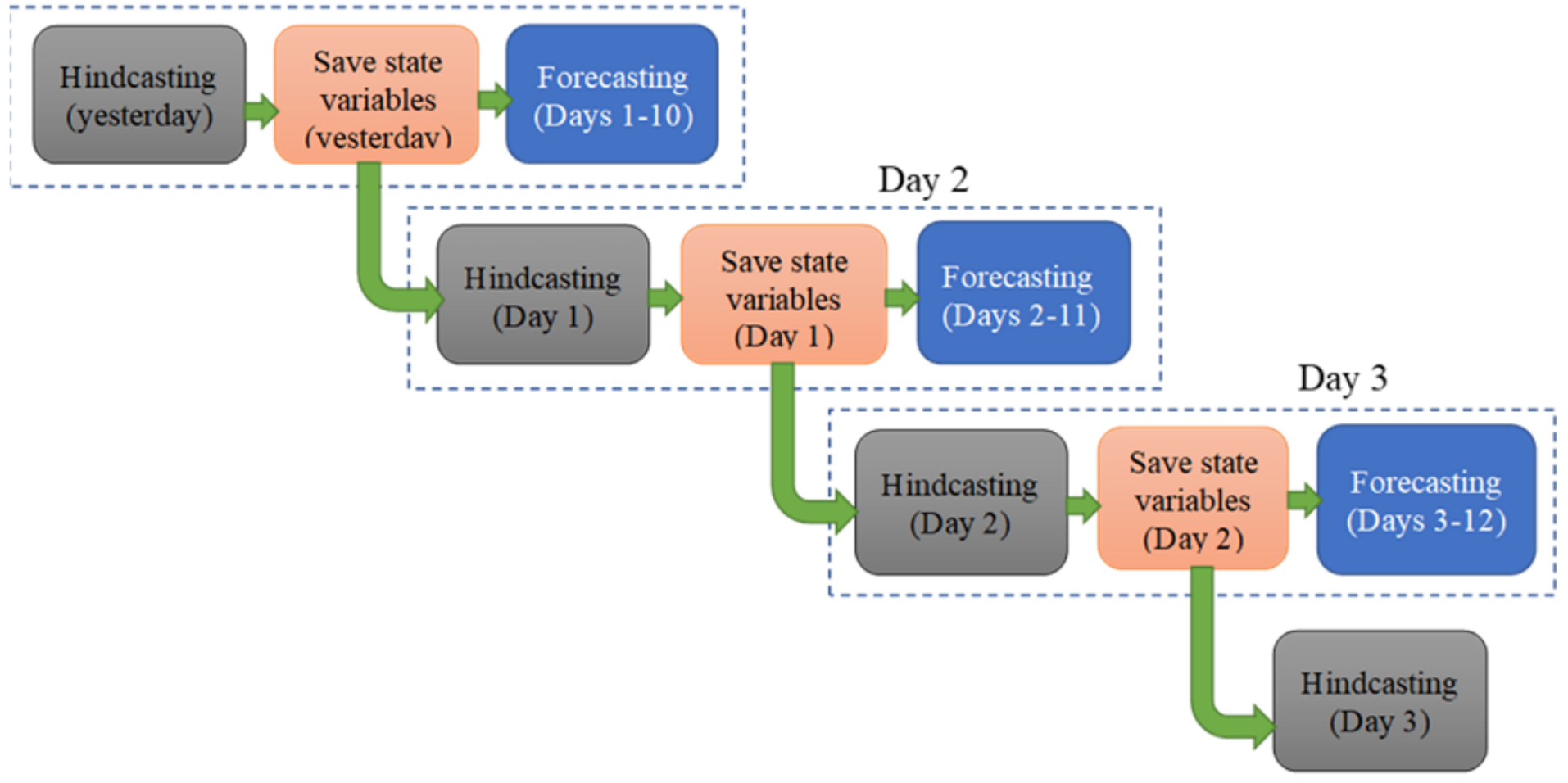

\section{Figure 2}

Schematic view of MESH operational streamflow forecasting setup

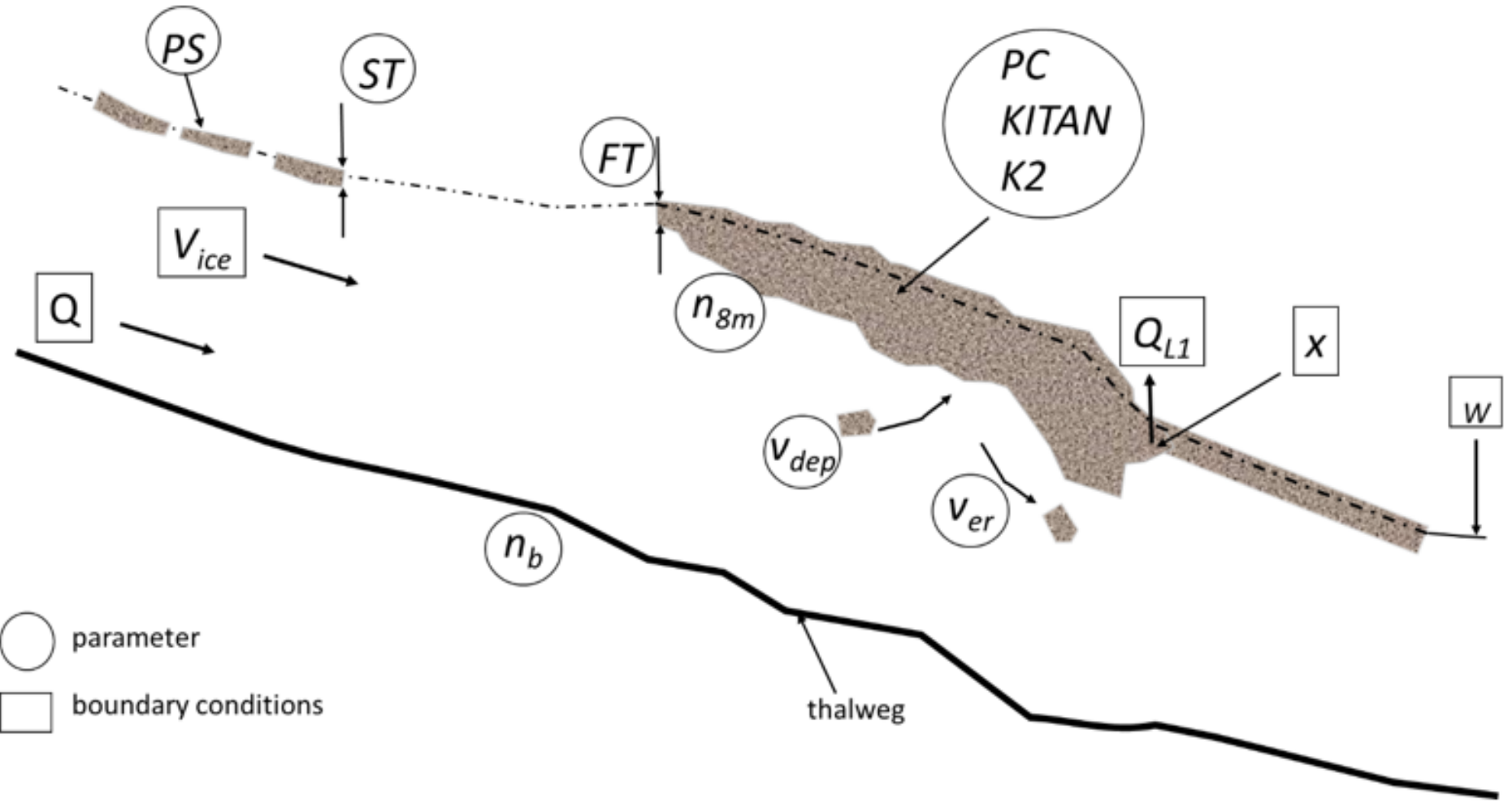

\section{Figure 3}

A conceptual diagram of the ice jam modelling using RIVICE. 


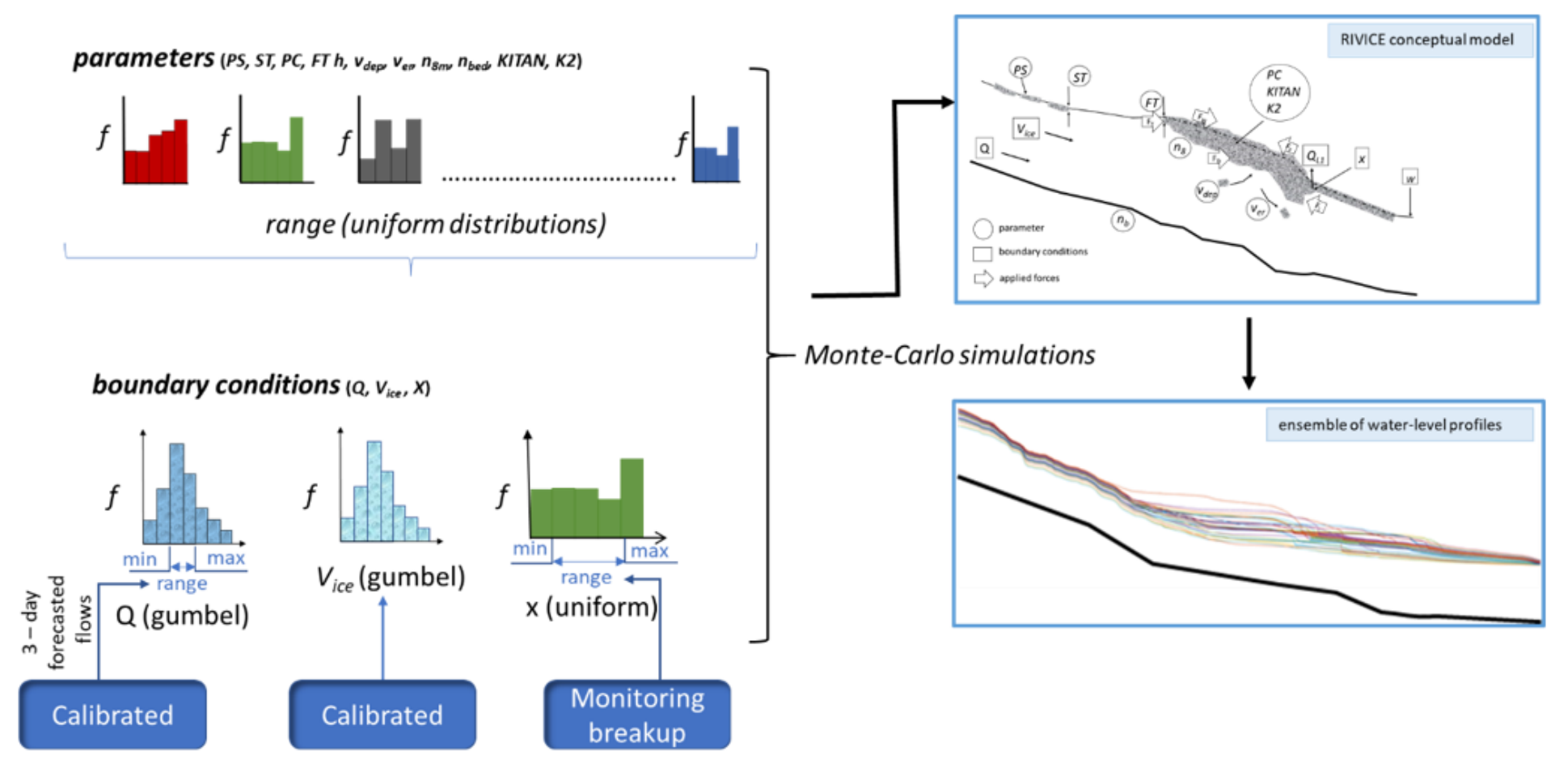

Figure 4

Stochastic framework for ice jam flood forecasting. 

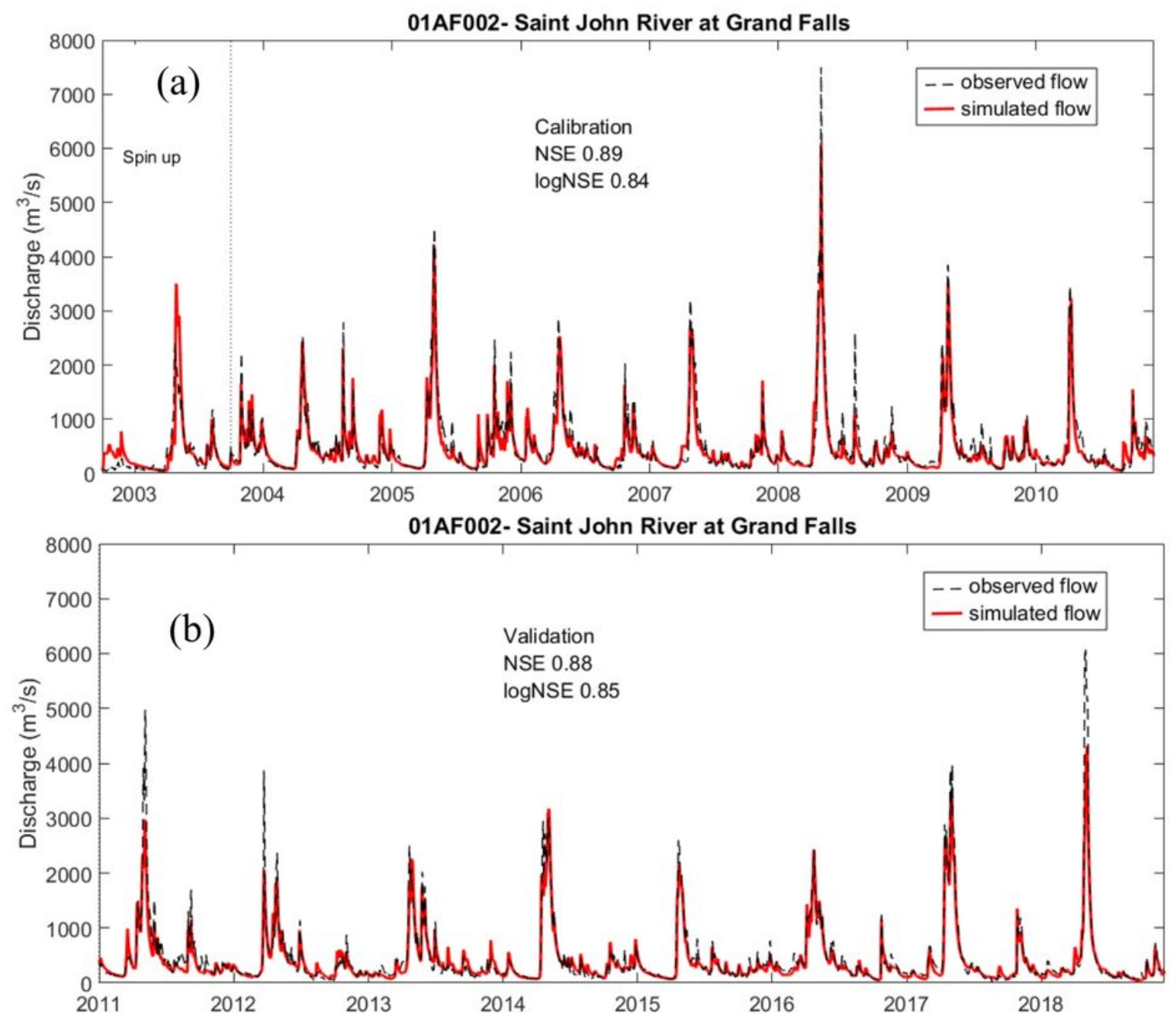

Figure 5

Observed and simulated flows at Grand Falls for the (a) calibration and (b) validation periods. 


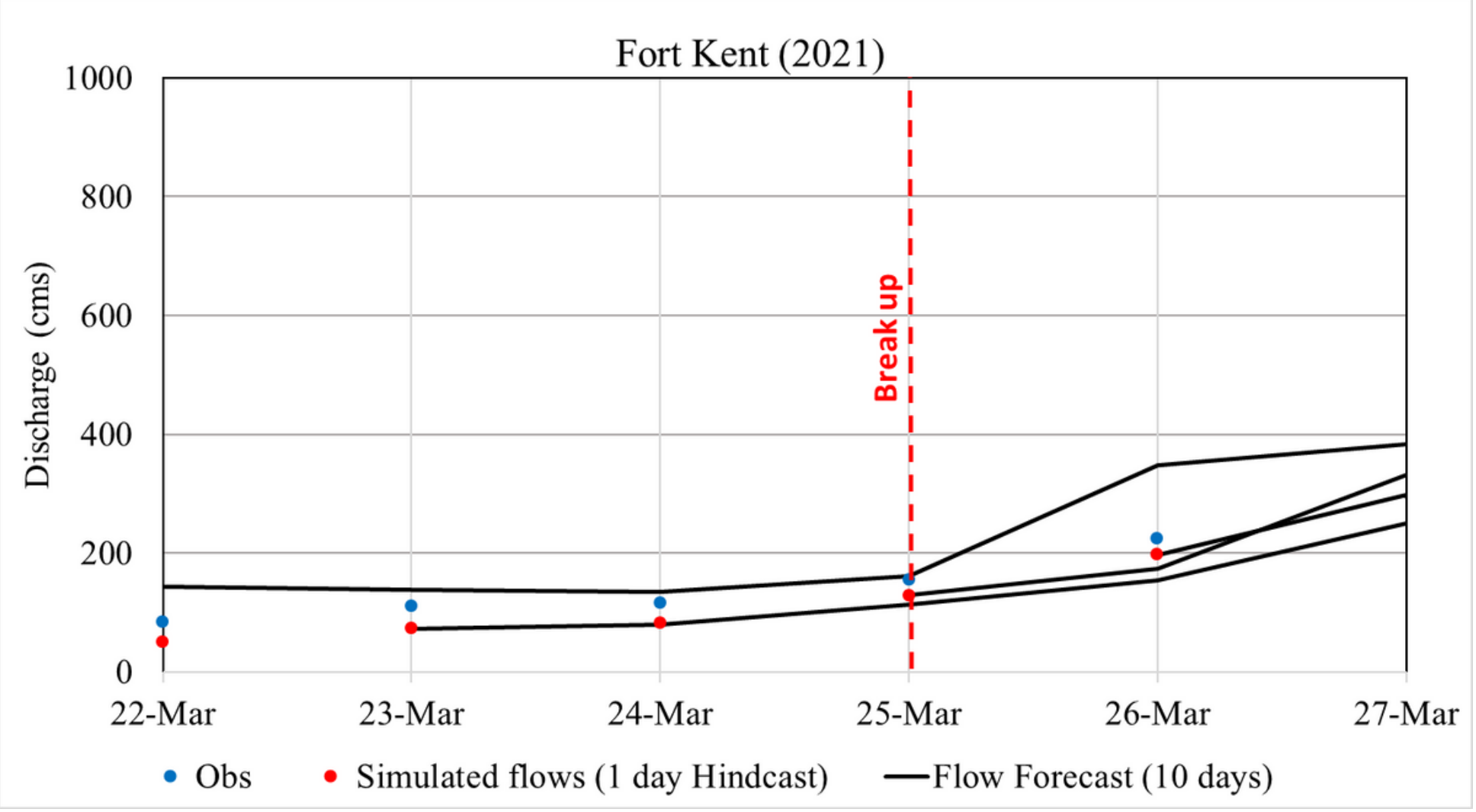

Figure 6

Forecast at Fort Kent (01AD002) for the spring breakup event in 2021.
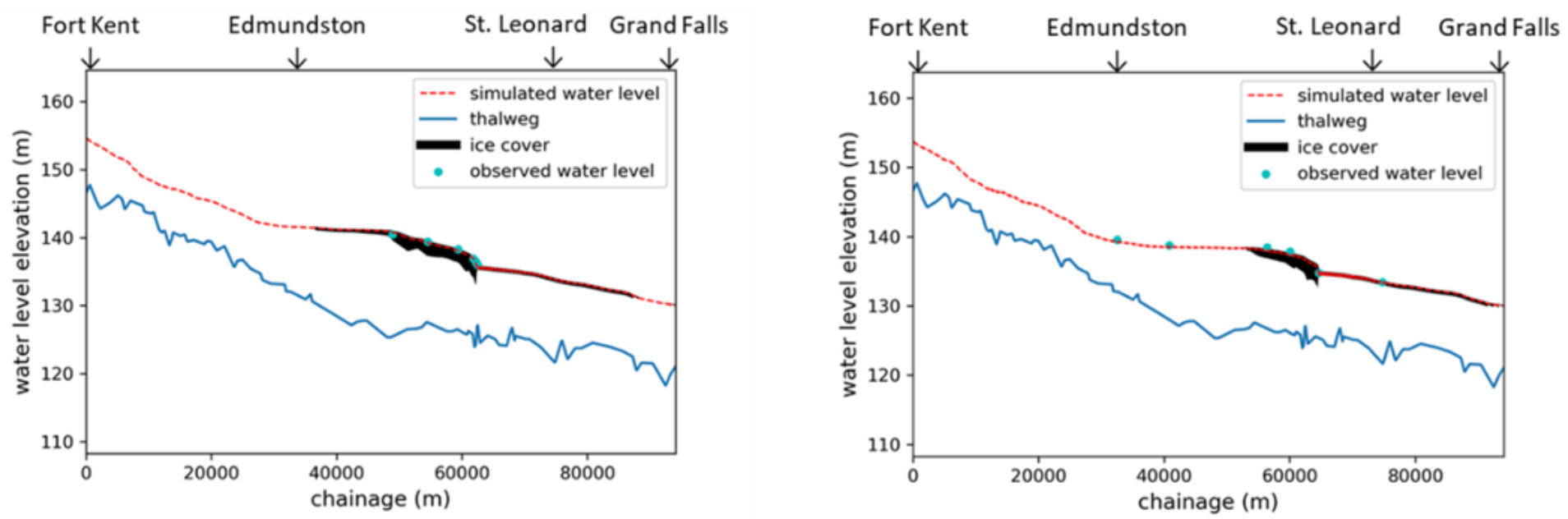

\section{Figure 7}

RVICE calibration (left panel) and validation (right panel) results using historical ice jam events in 1991 and 2009 along the model domain (data sources: Beltaos et al. 2012) 


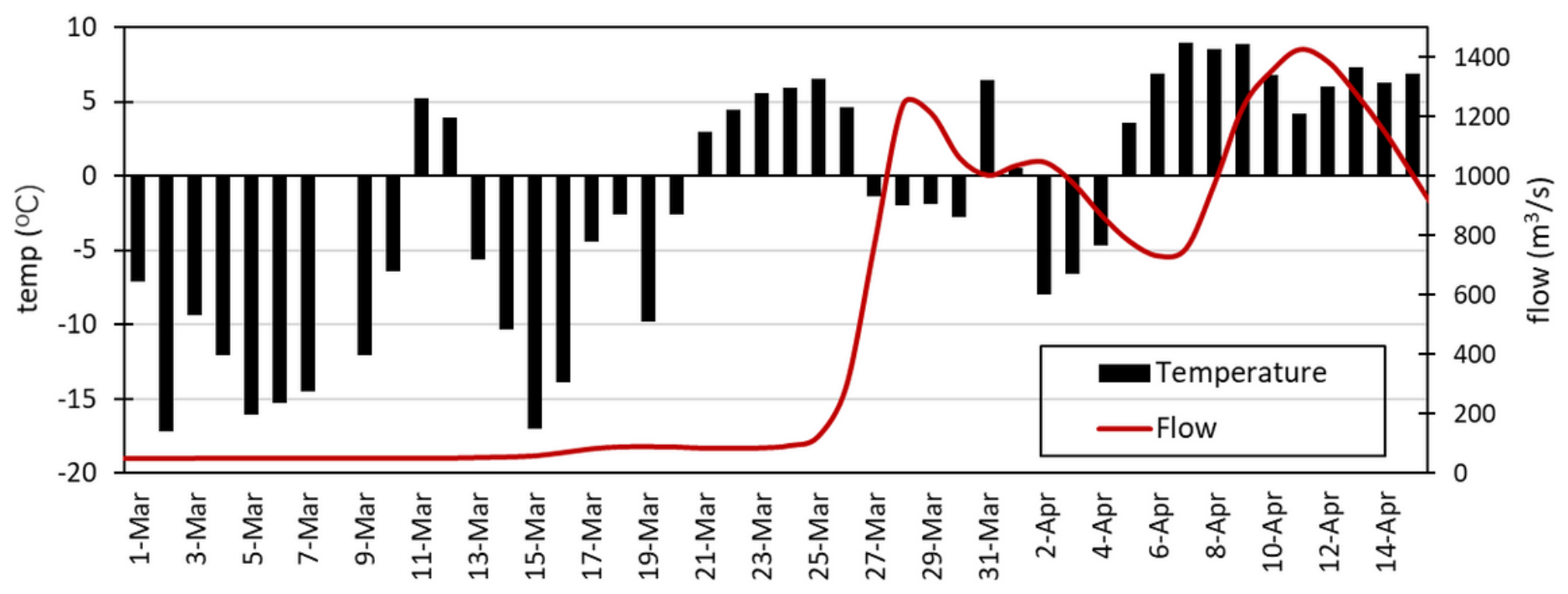

Figure 8

Daily mean streamflow at Fort Kent gauging station and air temperatures at the Edmundston meteorological station.

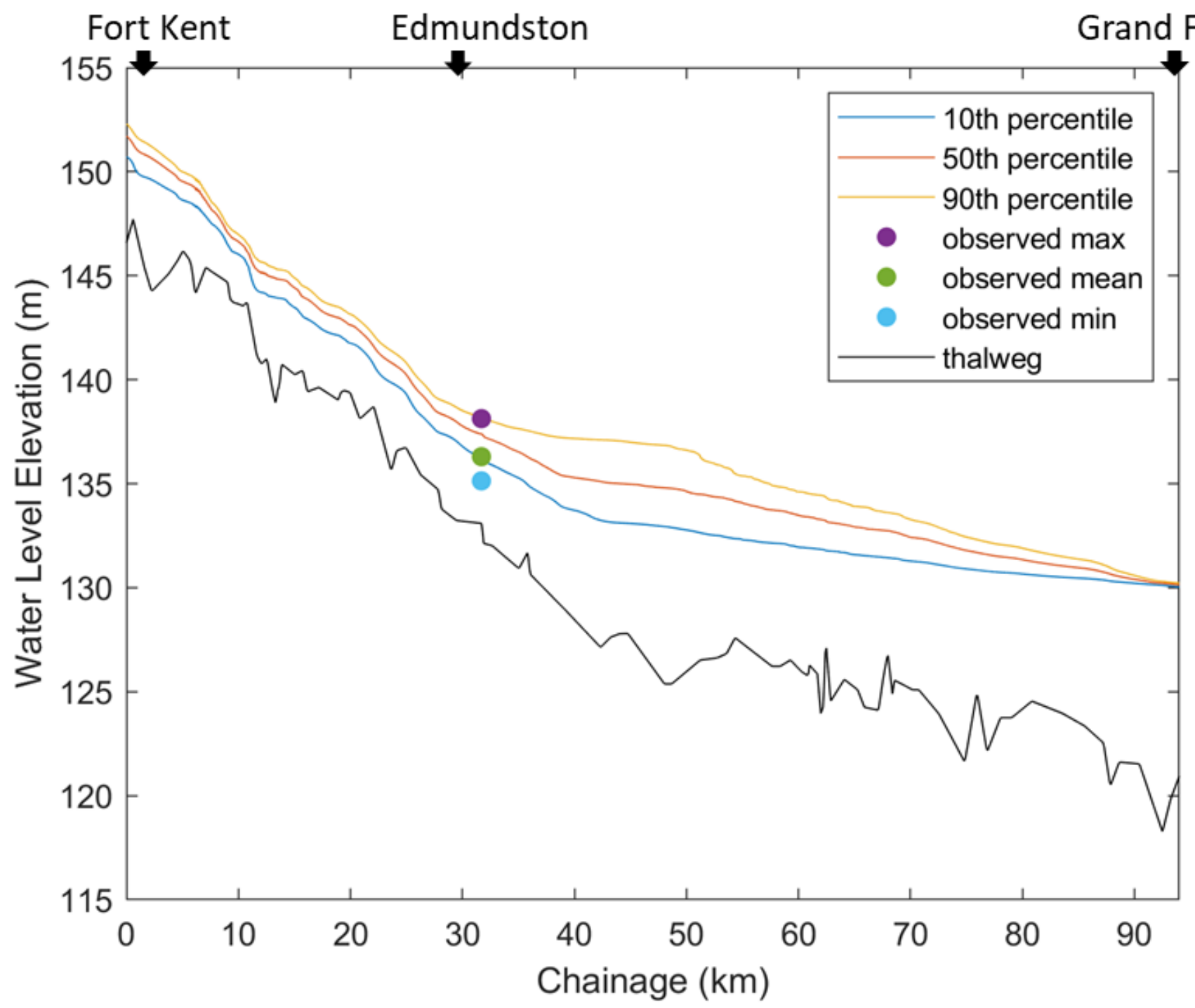


Figure 9

Ice jam flood outlook from 22 to 31 March 2021.
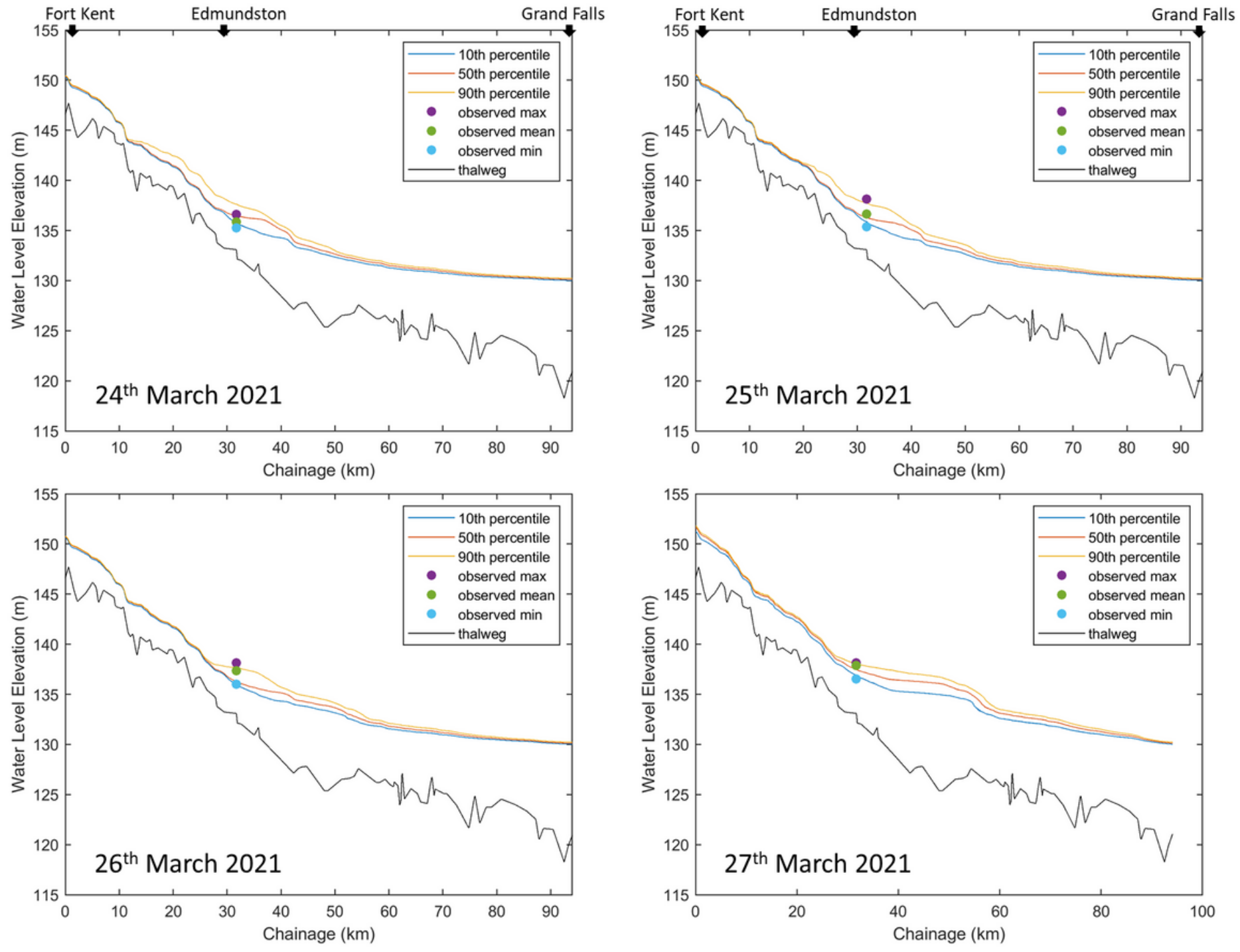

\section{Figure 10}

The 3-day ice jam flood forecasts from 24 to 27 March 2021 along the Saint John River from Fort Kent to Grand Falls. 